Teosofia: Indonesian Journal of Islamic Mysticism, Volume 7, Number 1, 2018

\title{
THE MEANING OF PANCASILA IN SUFISTIC PSYCHOLOGICAL PERSPECTIVE
}

\author{
Muhammad Zainur Rakhman \\ Ordo Futuwwah Institute \\ Zainur.Rakhman@ymail.com
}

\begin{abstract}
Pancasila has many functions for Indonesia; as the foundation of the state philosophy, the source of all law formations, nation's view of life, as well as the soul and personality of Indonesia. Pancasila has not become a common value that is the basic for every remark and behavior. Because of that Pancasila needs to be interpreted in useful point of view to build personality with deep contemplation of it. One of the signification is on Sufistic Psychology's Perspective. Sufistic Psychology as the development of Psychology based on Tasawuf, can be a useful perspective in interpreting Pancasila. Psycho-Sufistic that oriented in moral-transcendental can provide a deep and focused meaning to Pancasila. This research use a qualitative methodology, which elaborates the meaning of Pancasila in Sufistic Psychology's perspective. Before Pancasila was elaborated in Sufistic Psychology's perspective, the meaning of Pancasila was analyzed using semiotics. This study aims to interpret Pancasila in Sufistic Psychology's perspective.The results of the study shows that the research is useful to enrich the intellectual treasures of Pancasila.
\end{abstract}

Keywords. Pancasila, Tasawuf, Sufistic Psychology, Meaning, Semiotics

\section{A. Introduction}

The Indonesian nation is formed from cultural and ethnic diversity. The nation's history is a long dialectical process between thought and wisdom. Since the heyday of the kingdoms, the nation of the Archipelago has been divided into cultural loci which have developed very independently and firmly. After the proclamation of independence, the diversity was united in a state institution, with a unifying knot called the Pancasila. ${ }^{1}$

Pancasila, or the five orders that form the foundation of the state, is also used as a philosophy that becomes a view of life, ${ }^{2}$ and a guideline that shapes the personality and identity of the nation. Pancasila is also the source of all sources of law, which means to be the constitutional principle in which all the rules in the country stand upright on it. This centrality

\footnotetext{
${ }^{1}$ Yonky Karman, "Fundamentalisme Pancasila”, Kompas, Saturday, June 10, 2017.

${ }^{2}$ Tukiran Taniredja, Indonesia Baru; Empat Konsensus Satu Dasar Berbangsa dan Bernegara Indonesia, (Yogyakarta: Penerbit Ombak, 2015), 59.
} 
makes the Pancasila position very important and vital. Pancasila can be said to be the soul or spirit of the Indonesian nation. ${ }^{3}$

After independence, the history of the Indonesian nation was divided into several periods: the old order, the new order, and the reform order. The history also becomes the history of Pancasila, where in each order, Pancasila is played differently. Pancasila is interpreted differently, especially by the power elite, which tends to make it a political tool. During the old order, Pancasila was played as a single state ideology and became a comprehensive cultural politics. The fruit of this meaning has created authoritarianism, which in practice tends to be used by the communist left. ${ }^{4}$ The new Order then adds the role of Pancasila, not only as a single principle, but also the guarantee of the well-being and well-being of the Indonesian people. New Order is trying to make Pancasila not only as supra-ideology, as well as living ideology through the P-4 program. ${ }^{5}$

The reform order sought to eliminate the tendency of the Pancasila exponents as a political tool. The reform order also sought to avoid all indoctrination and coercion of a single interpretation of Pancasila. Of course that is positive for the life of democracy. However, as a result in several periods of leadership, Pancasila was only interpreted as a formality. Excessive concerns about indoctrination in the New Order style, resulted in programs to strengthen and internalize Pancasila becoming stagnant and almost disappearing from the agenda of national life. Although stretching towards the strengthening of the Pancasila has begun to strengthen lately, with its diversity being highlighted, the meaning of the Pancasila has not yet touched the personal realm of every individual human Indonesia.

Pancasila has not yet become values that form a noble personality and moral behavior ${ }^{6}$ The slogan, "I am Indonesian, I am Pancasila" has not been interpreted in depth, becoming a spirit that illuminates the norms of the lives of individuals and society. Evidently in many cases and events that occurred in the community, the spirit of Pancasila was not fully present. The public can still be vigilant, still easily provoked by false news, and easily polarized with religious and political issues. National life is characterized by seven social sins (borrowing Gandhi's term), namely: principleless politics, wealth without hard work, commerce without morality, conscience without education, education without character, science without humanity, and worship without sacrifice. ${ }^{7}$

\footnotetext{
${ }^{3}$ Ibid., 71 . 2016), 39.

${ }^{4}$ Syaiful Arif, Falsafah Kebudayaan Pancasila; Nilai dan Kontradiksi Sosialnya, (Jakarta: Gramedia,

${ }^{5}$ Syaiful Arif, Falsafah Kebudayaan..., 43.

6 Yudi Latif, Negara Paripurna; Historisitas, Rasionalitas, dan Aktualitas Pancasila, (Jakarta: Gramedia, 2015), 49

${ }^{7}$ Yudi Latif, Negara Paripurna..., 48.
}

Teosofia: Indonesian Journal of Islamic Mysticism, Volume 7, Number 1, 2019 
Indonesian people basically do not have identity clarity ${ }^{8}$ Individuals in society have a variety of opposing thoughts and interests, each of which feels they have the truth. Human Indonesia has not made Pancasila as shared values, which form a noble personality, which is a moral basis in attitude, speech, and taking action. Therefore, the meaning of Pancasila is needed which is able to encourage the formation of a noble Indonesian human personality.

Sufistic Psychology, a development of psychology based on Sufism, ${ }^{9}$ is the right science to study Pancasila as the soul of the nation, in order to shape this personality. Pancasila needs to be studied in the perspective of psychology, because Pancasila itself is the soul of the Indonesian nation, the spirit or spirit that was unearthed from the civilization of the archipelago for centuries. ${ }^{10}$ However, it is not enough with a psychological study, but a transducer-oriented psychology, which has been included in the teachings of tasawuf.

\section{B. SUFISTIC PSYCHOLOGY}

\section{Definition and Scope of Sufistic Psychology}

Sufistic Psychology is a science of human behavior whose concepts are built based on the paradigm of Sufism. ${ }^{11}$ Sufistic Psychology is a scientific development of psychology based on Sufism teachings. In linguistic terms, Sufism means the nature or style of Sufism, so Sufistic Psychology can be said to be a psychology of Sufism. The scientific framework still uses the western scientific framework, but paradigmally the substance uses the paradigm of Sufism. ${ }^{12}$ In scientific tradition, this is like philosophical mysticism, namely Sufism which has a philosophical pattern. ${ }^{13}$

Sufistic Psychology, gives direction and purpose for psychological science, so it is not value free. ${ }^{14}$ Sufistic Psychology guides towards commendable psychological behavior. By

\footnotetext{
${ }^{8}$ Franz Magnis Suseno, Berebut Jiwa Bangsa, (Jakarta: Penerbit Buku Kompas, 2006), 204

${ }^{9}$ Abdullah Hadziq, Rekonsiliasi Psikologi Sufistik dan Humanistik, (Semarang: Rasail, 2005), 24.

${ }^{10}$ Syaiful Arif, Falsafah Kebudayaan..., 33.

${ }^{11}$ Abdullah Hadziq, Rekonsiliasi Psikologi Sufistik..., 24.

12 The word 'sufistic' is an absorption of sufistic, which shows the nature or style, in this case the nature
} and style in question is sufism or Sufism.

${ }^{13}$ Philosophy Sufism is Sufism developed with philosophical features, after the contact of the Islamic world with the influence of Greek philosophy. Philosophy Sufism is a variety of developments in Sufism, in the IV century. The characters are Sufis who are also philosophers, such as Ibn 'Arabi, and Suhrawardi. Amin Syukur dan Fatimah Usman, Insan Kamil; Paket Pelatihan Seni menata Hati, (Semarang: Yayasan Al Muhsinun Semarang, 2006), 5.

${ }^{14}$ Abdullah Hadziq, Rekonsiliasi Psikologi Sufistik..., 38. 
using the concept of Sufism Takhalli, Tahalli, and Tajalli, ${ }^{15}$ it can foster psychological maturity and the integrity of the human soul. ${ }^{16}$

Sufistic Psychology also extends the scope of the psychology area, not only to the observable area, but also extends to conceivable areas, even to unconceivable areas. ${ }^{17}$ The universe as an observed reality is not the only reality, because the universe is only a sign of a more true divine reality. ${ }^{18}$ This allows the use of the kasyf method or intuition as one of the sources of truth in Sufistic Psychology. ${ }^{19}$ This scientific limitation on Sufism, lies in its object which only focuses on the soul, as the science of psychology. ${ }^{20}$ While Sufism has a very broad object, not only in the human psyche, but in the dimensions of divinity, prophecy, and inheritance.

\section{Platform for Ontology of Sufistic Psychology}

Sufistic psychology sees the reality of existence, both the macrocosm and the microcosm, in three fundamental conditions, namely the material state, the psychological state, and the spiritual-transcendental state. ${ }^{21}$ The material state is a physical state that can be sensory perception. Sufistic psychology does not deny outward phenomena, things that are factually visible to the eye, heard by the ear, and felt by other senses. Psychic state is an inner dimension, which can be felt by the human soul. This dimension is a situation that every human being can also factually feel. Sufistic Psychology, recognizes the psychological dimension of man who can determine the good and bad behavior of a person.

The spiritual-transcendental state is a typical ontological dimension in Sufistic Psychology. A situation that is far more sublime than a psychological dimension, which is related to the realm of divinity. This makes Sufistic Psychology more comprehensive in absorbing reality, and able to read the existence as a whole. Positive Western science, looking at reality is only limited to the terindra region. This is a distortion of reality, which nullifies the existence and role of God in existence. ${ }^{22}$ Furthermore, this view ultimately releases the knowledge of values.

\section{Epistemology of Sufistic Psychology}

${ }^{15}$ Takhalli, means to expel, ie to expose the reprehensible qualities in the soul. Tahalli, means adorning the soul or filling the soul with praiseworthy qualities, and when the soul is established in a certain level reaches tajalli, or the disclosure of nur ghalib, which makes the soul clean so that it is able to capture the light of God. Amin Syukur, Sufi Healing, (Jakarta: Erlangga, 2012), 13.

${ }^{16}$ Abdullah Hadziq, Rekonsiliasi Psikologi Sufistik.., 25.

${ }^{17}$ Ibid, 26

${ }^{18}$ Mulyadi Kartanegara, Nalar Religius, (Jakarta: Erlangga, 2007), 38.

${ }^{19}$ Abdullah Hadziq, Rekonsiliasi Psikologi Sufistik..., 33.

${ }^{20}$ It can be said, Sufistic Psychology is a systematization of Sufism that focuses on the soul. The difference with Islamic Psychology is its specificity in using the teachings of Sufism as a basis, and its uniqueness in the use of the Kasyf (intuition) method which is not used in Islamic Psychology. Sufistic Psychology is certainly Islamic, but Islamic Psychology is not necessarily Sufistic.

${ }^{21}$ Abdullah Hadziq, Rekonsiliasi Psikologi Sufistik..., 26.

${ }^{22}$ Mulyadi Kartanegara, Nalar Religius ... , 39.

Teosofia: Indonesian Journal of Islamic Mysticism, Volume 7, Number 1, 2019 
Epistemology as a theory of knowledge that discusses the sources of truth is closely related to metaphysics or ontology. ${ }^{23}$ Sufistic Psychology, in accordance with the area that is the object of its study, it requires a method that is able to understand the totality of humanity, in the dimensions of physical and spiritual, individual and social, as well as the world and the hereafter. $^{24}$

Spiritual spirit is used to study science by collaborating mind and heart to understand human phenomena and their relationship with the universe. ${ }^{25}$ So, epistemologically, the methods used in Sufistic Psychology include:

a. Method of Mulâhazah Țabî'iyyah

This method is a natural observation method that explores the state of the soul through observable behavior. The basis of this method is the close relationship between mental states and outward behavior, which cannot be separated. ${ }^{26}$ This method is also used in Western Psychology, known as naturalistic observation. This method is used to observe behavior in a place by seeking a natural condition, which is unobstrusive, so that the presence of an observer does not cause a behavioral bias from the subject being observed. ${ }^{27}$

b. Method of Tajrîb Rûhanî

This method is referred to as the spiritual experimental method, which performs specifically spiritual nuances, by simplifying the observed symptoms. This method aims to find a causal relationship between psychological behavior with spiritual behavior. ${ }^{28}$

c. Method of Muhâsabah

This method is a method of reviewing the conscience, whether the action is right or wrong. This method requires a well-integrated self, where the ego has been transformed with exercises. $^{29}$

d. Method of Scripture Interpretation

This method is an absolute method in Sufistic Psychology as a scientific consequence based on the teachings of Sufism which originates from the scriptures. This method as a means of obtaining ultimate truth is beyond the reach of reason and the senses. ${ }^{30}$ The scriptures basically gather all kinds of knowledge, signs, and parables that exist in the universe. The truth that is in the scriptures is the truth without any doubt at all. ${ }^{31}$

\footnotetext{
${ }^{23}$ Asmoro Achmadi, Filsafat Umum, (Jakarta: Raja Grafindo, 2011), 15

${ }^{24}$ Abdullah Hadziq, Rekonsiliasi Psikologi Sufistik..., 26.

25 Ibid., 27.

26 Ibid., 28.

${ }^{27}$ Jeffrey S. Nevid, dkk., Psikologi Abnormal Jilid I, Terj: Jeanette Murad, dkk., (Jakarta: Erlangga,

${ }^{28}$ Abdullah Hadziq, Rekonsiliasi Psikologi Sufistik..., 29.

${ }^{29}$ Ibid., 30.

${ }^{30}$ Abdullah Hadziq, Rekonsiliasi Psikologi Sufistik..., 33.

${ }^{31}$ Musa Kazhim, Tafsir Sufi, (Jakarta: Lentera, 2003), 100-101.
} 2003), h. 20. 
e. Method of Kasyf

This method can be said as a unique method in Sufistic Psychology, where truth or knowledge can be reached intuitively as a result of cleansing the heart through means of mujâhadah and riyâdah. ${ }^{32}$ The knowledge that comes from the awareness of the heart is called dzauq. This dzauqi knowledge comes from the science of ladunni who comes to a clean heart that is exposed from all the defilements of lust. ${ }^{33}$

\section{The cornerstone of Sufi mystic psychology}

The axiological dimension is the focus of scientific Sufi Psychology. ${ }^{34}$ In contrast to Western scholarship which emphasizes the methodological aspects, Sufistic Psychology views that all scientific products must be moral, not free of value, and can be utilized for the benefit of humanity, in the faith, worship, and worship. ${ }^{35}$

The purpose of a science must be useful in strengthening moral values, and providing benefits for civilization. Science should increase faith and knowledge with God. ${ }^{36}$ The concept of Western science that is value-free, makes it axiologically flawed, so that its products often only cause new problems that have no end. Sufistic Psychology emphasizes the use of science that aims at morals, which strengthens values, and pays attention to the consequences of each theory that is triggered, whether encouraging the strengthening of humanity's noble values or actually reducing the nature of humanity.

\section{Basic Perspective of Sufistic Psychology}

The Sufistic Psychology Perspective is a Sufistic Psychology perspective in seeing phenomena that are based on scientific principles of Sufistic Psychology, which are based on three things: first, Anthropo-Religious-Centric Patterns; second, Dual Purpose Orientation, and third, Moral Perfection. ${ }^{37}$

\section{a. Anthropo-Religious-Centric Model}

Sufistic Psychology centers on the religious nature of humanity. The religious potential of humans becomes the focus of scientific development and goals in each study. Humans are basically creatures that are at once. Humans have the glory of the soul that must always be improved and perfected. With a focus on human noble values, Sufistic Psychology is not trapped in a view that reduces humanity.

b. Dual Purpose Orientation

${ }^{32}$ Abdullah Hadziq, Rekonsiliasi Psikologi Sufistik..., 34.

${ }^{33}$ Fu'ad Farid Ismail dan Abdul Hamid Mutawalli, Cara Mudah Belajar Filsafat (Barat dan Islam), Terj: Didin Faqihudin, (Yogyakarta: IRCiSoD, 2012), 189.

${ }^{34}$ Abdullah Hadziq, Rekonsiliasi Psikologi Sufistik..., 39.

${ }^{35}$ Ibid.

${ }^{36}$ Mulyadi Kartanegara, Nalar Religius ..., 45.

37 Abdullah Hadziq, Rekonsiliasi Psikologi Sufistik..., 191.

Teosofia: Indonesian Journal of Islamic Mysticism, Volume 7, Number 1, 2019 
Sufistic Psychology is different from Western psychology which has only a single purpose. Sufistic Psychology has worldly and ukhrawi oriented goals. Worldly orientation is directed at developing the balanced potential of the human soul, so as to be able to carry out humanitarian tasks, and to carry out a noble life. The ukhrawi's orientation makes human beings as pious, sincere, and charitable servants of God in search of God's good pleasure, so as to get the reward of salvation and happiness in the eternal life of the hereafter.

c. Moral Perfection

Sufistic Psychology emphasizes the axiological dimension which gives attention to moral perfection. Moral perfection is something that is very possible to be achieved by humans. Moral perfection certainly signifies a healthy and stable soul and personality. With an orientation to moral perfection, Sufistic Psychology has a clear purpose, so that there are signs that can avoid deviations and futility.

\section{PANCASILA AND ITS MEANING}

\section{Pancasila Text}

Pancasila was substantially formulated in the BPUPKI meeting. The result was the Jakarta Charter which contained Pancasila. After being reconciled in the PPKI meeting, there was a change in the first precept, namely the seven-word deletion, "the obligation to carry out Islamic law for its adherents." 38

In terms, the naming of Pancasila was first coined by Ir. Soekarno, on June 1, 1945. The name Pancasila derives from the Sanskrit language, Panca which means five, sila which means order, meaning five principles or bases held in realizing the national and state order. ${ }^{39}$

Pancasila is contained in the last paragraph of the opening of the 1945 Constitution, stating clearly that Pancasila is the basis of the state. The five precepts are, ${ }^{40}$

1. The Almighty God

2. Fair and civilized humanity

3. Indonesian Unity

4. Democracy Led by Wisdom in Consultation / Representation

5. Social Justice for All Indonesian People

\section{The Meaning of Pancasila Semiotics (Pre Analysis)}

Semiotic analysis is a text analysis that seeks to uncover the structure of linguistic texts as a sign system that is interpreted arbitrarily. This analysis enables the meaning of contextual and contemporary Pancasila. Semotic as a science formulated by Pierce, is a theory of signs. ${ }^{41}$ Umberto Eco, gives an understanding of the sign is everything, which represents something

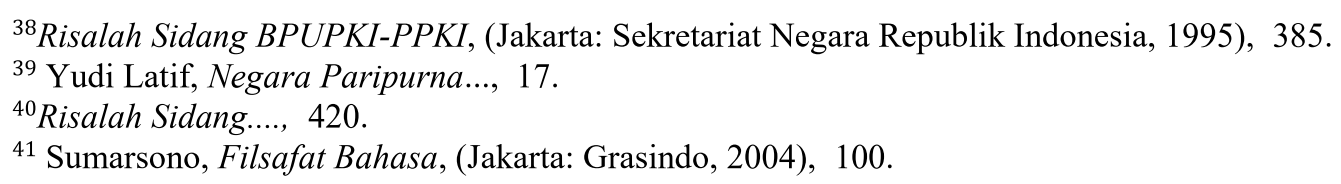


else. ${ }^{42}$ Thus, language is also a sign system. Text as a medium of language, is also a sign structure. In the concept, there are three components of the sign: the sign (which marks), the sign (which is marked), and the referent. ${ }^{43}$ Put simply, markers are forms, markers are meaning, and referents are thoughts or concepts. In the application, each word is a form (marker), while the meaning of the word is a sign, which is very dependent on the referent or mind that connects the marker with the sign (the subject that interprets the sign). In Pierce's term, it is called a triangle sign: words are shapes (markers) called representations. Meaning or signified, is the object represented. While ideas or referents, namely thoughts that connect words with meaning, markers with markers, or representations with their objects, are called interpretants. ${ }^{44}$

Pancasila as a sign system, in this case uses the Charles S. Pierce semiotic model. Pierce's sign theory is a theory that provides more flexibility in reasoning, than operational steps that are technical in nature. Each word in the Pancasila text is a sign that will be dismantled, into three components, the shape of the word itself, thoughts about the word, and the meaning that emerges from that thought. By unpacking every word in the Pancasila text, contextual and present meaning will be found.

Semiotics is used in interpreting Pancasila as a sign system, in this case using the Charles S. Pierce semiotics model. Pierce's sign theory was chosen with the argument that Pancasila is not a conventional sign. Pancasila is not a literary work, nor is it a communication message or a spectacle. Pancasila is a conception of culture. A cultural conception, it is more appropriate to use reason (logic) in studying it.

Pierce's sign theory is a relatively simple theory, so that it provides more reasoning flexibility (for Pierce semiotics is synonymous with logic), rather than operational steps that are technical. Every thing is a sign (can be treated as a sign), and in every sign, there are three things contained in it. First, representation, second object, third is interpretant. An easy illustration, the word "STOP" with a red background at an intersection indicates that every car must stop if it is in front of him. The representation is the word "STOP", the object is "stop", and the interpretation is the idea that connects representation with the object. This concept is known as Pierce's triangle sign, and in this concept, the sign system in the Pancasila will be dismantled (analyzed) one by one. ${ }^{45}$

\section{The Semiotic Meaning of 'Almighty God'}

The Almighty God is a sign, which represents the faith or belief in an absolute sole authority, as a point of origin as well as a point of destination for everything, including national and state life. The Godhead is the representation, while the object is the faith or belief in the

\footnotetext{
${ }^{42}$ Umberto Eco, Teori Semiotika, (Yogyakarta: Kreasi Wacana, 2009), 22.

${ }^{43}$ Sumarsono, Filsafat Bahasa, 108.

${ }^{44}$ Wildan Taufiq, Semiotika untuk Kajian Sastra dan al-Qur'an, (Bandung: Yrama Widya, 2016), 32-35.

${ }^{45}$ Ibid. 31.
}

Teosofia: Indonesian Journal of Islamic Mysticism, Volume 7, Number 1, 2019 
existence of a single, absolute authority and governs everything. The interpretation is the existence of worship and devotion, both direct and ritual in nature in all aspects of life through obedience to God's rules and laws. Worship and devotion are the link between God as a representation and faith as an object. That is, worship as a consequence of the relationship. Thus, the semiotic meaning of the 'Godhead of the Almighty' is a confession of faith in the existence of God, which demands worship or devotion to Him.

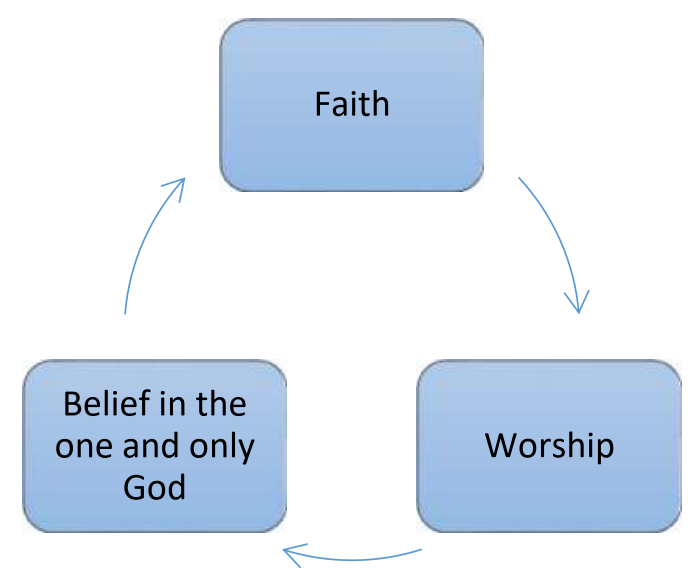

Scheme 1. The First Triangle of Principle

\section{The Meaning of Semiotics 'Just and Civilized Humanity'}

Just and civilized humanity as a sign, signifying an anthropocentric orientation, that is, humans as the center in seeing everything in life. Humans are the subject of the perpetrators. Thus, just and civilized humanity is a representation, where the object is the anthropocentric orientation of life, so that the interpretation is that humans are fully responsible for whatever happens in their lives. Human responsibility is both a link and a logical consequence between humanity and anthropology. Humans are the main bearers. As the main responsibility, human beings are required to be fair and civilized. In conclusion, the semiotic meaning of 'Just and Civilized Humanity' is that humans are the center of life, so that humans become the main responsible in everything that happens in life, so humans are required to be just and civilized. 


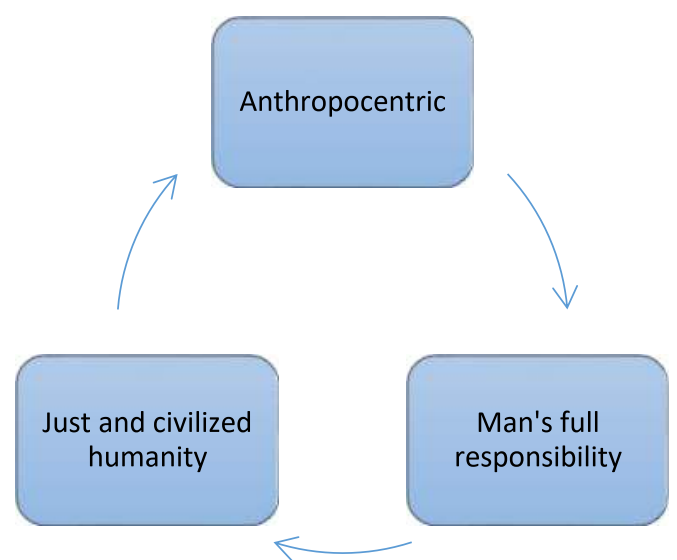

Scheme 2. The Second Meaning of Precepts Triangle

\section{The Meaning of Semiotics 'Indonesian Unity'}

Indonesian Unity is a sign that represents a process of diversity (diversity) into a single unit. Indonesian unity is representation, the object is diversity. Thus, the interpretation is cooperation and harmony, as a consequence that connects unity with diversity. Cooperation and harmony become a link between unity and diversity. So, the semiotic meaning of the principle of 'Indonesian Unity' is the existence of diversity which processes into one unit, so there is a need for cooperation and harmony in realizing such unity.

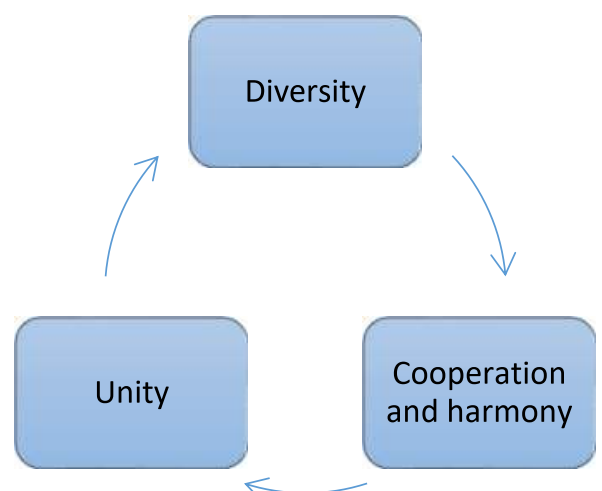

Scheme 3. Triangles of Meaning of the Third Principle

\section{The Meaning of Semiotics 'Democracy Led by Wisdom Wisdom in Representative Consultation'}

Democracy as a sign, represents a sovereignty or supreme power. Democracy is a representation, the object is sovereignty or power. Therefore, the interpretation is that the people's interests are the most important priority. In formulating the interests of the people, it is necessary to weigh in wisdom, meaning that it is necessary to consider using common sense 
and conscience. Priority to the interests of the people becomes both a link and a logical consequence between democracy as a representation and the sovereignty of the people as the object of its representation. In conclusion, the semiotic meaning of the fourth precept is that people's sovereignty is the highest sovereignty, so that people's interests are the top priority. In compiling its interests, it is necessary to deliberate within the frame of wisdom or wisdom.

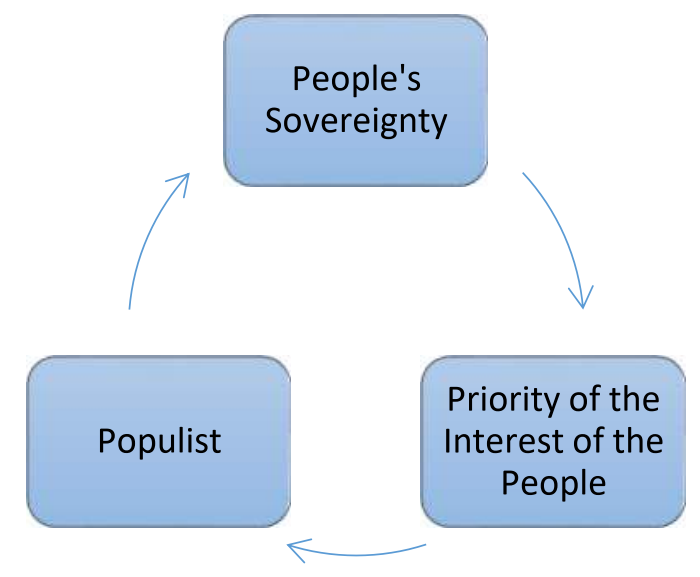

Scheme 4. Triangles of the Fourth Principle

\section{The Meaning of Semiotic 'Social Justice for All Indonesians'}

Social justice as a sign, represents togetherness in terms of welfare. Social justice is a representation, the object is togetherness in welfare. Then, the interpretation is there must be equity, which eliminates social inequality. Equity is a connecting and logical consequence between social justice as a representation and togetherness in welfare as the object represented. Thus, the semiotic meaning of the fifth precept is togetherness in prosperity which is realized by the existence of equal distribution in an effort to eliminate social inequalities.

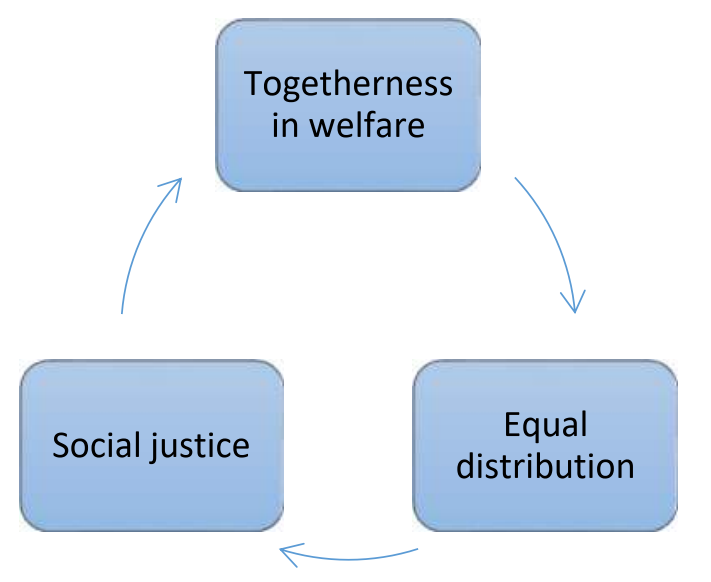

Scheme 5. The Meaning of Fifth Sila Triangle 
In summary, the triangle meaning and the semiotic meaning of Pancasila can be seen in the table as follows:

Table 1. Semiotic Meanings of Pancasila

\begin{tabular}{clll}
\hline Principle & \multicolumn{1}{c}{ Representation } & \multicolumn{1}{c}{ Object } & \multicolumn{1}{c}{ Interpretation } \\
\hline 1 & $\begin{array}{l}\text { Belief in the one } \\
\text { and only God }\end{array}$ & Faith & Worship \\
\hline 2 & $\begin{array}{l}\text { Fair and civilized } \\
\text { humanity }\end{array}$ & $\begin{array}{l}\text { Anthropocentric } \\
\text { life }\end{array}$ & $\begin{array}{l}\text { Man is enthusiastic as the main } \\
\text { responsibility }\end{array}$ \\
\hline 3 & $\begin{array}{l}\text { the unity of } \\
\text { Indonesia }\end{array}$ & Diversity & Cooperation of shelters \\
\hline 4 & Populist & $\begin{array}{l}\text { Sovereignty and } \\
\text { power }\end{array}$ & $\begin{array}{l}\text { The interests of the people are the } \\
\text { main priority }\end{array}$ \\
\hline 5 & Social justice & $\begin{array}{l}\text { Togetherness in } \\
\text { welfare }\end{array}$ & Equal distribution \\
\hline
\end{tabular}

Table 2. The Semiotic Meaning of Pancasila

\begin{tabular}{cll}
\hline Principle & \multicolumn{1}{c}{ Representation } & \multicolumn{1}{c}{ Semiotic Meaning } \\
\hline 1 & $\begin{array}{l}\text { Belief in the one and } \\
\text { only God }\end{array}$ & $\begin{array}{l}\text { His acknowledgment of God, who demanded } \\
\text { worship or devotion to Him. }\end{array}$ \\
\hline 2 & $\begin{array}{l}\text { Fair and civilized } \\
\text { humanity }\end{array}$ & $\begin{array}{l}\text { Humans are the center of life, so that human } \\
\text { beings are responsible for everything in } \\
\text { everything that happens in life, human life is } \\
\text { demanded for and civilized. }\end{array}$ \\
\hline 3 & the unity of Indonesia & $\begin{array}{l}\text { Diversity that proceeds into unity, then requires a } \\
\text { lot of cooperation between the two companies in } \\
\text { realizing the unity. }\end{array}$ \\
& Populist & $\begin{array}{l}\text { The sovereignty of the people is the highest } \\
\text { sovereignty, so that the interests of the people } \\
\text { constitute the first priority. In terms of its } \\
\text { importance, then it is a discussion of wisdom in } \\
\text { wisdom or wisdom. }\end{array}$ \\
\hline 5 & Social justice & $\begin{array}{l}\text { Togetherness in the well-being that is manifested } \\
\text { in the presence of equity in the effort eliminates } \\
\text { social inequality. }\end{array}$ \\
\hline
\end{tabular}
D. The Meaning Of Pancasila In The Perspective Of Sufistic Psychology: The Meaning of God in the Perspective of Sufistic Psychology


Semiotic divinity is interpreted as a confession of faith in the existence of God, which demands worship or devotion to Him. Philosophically, divinity emphasizes ethical commitment to the values of morality and spirituality as an important and vital foundation in the nation's performance and sustainability. This meaning in the perspective of Sufistic Psychology is seen in three principles (anthropho-religious-centric style, dual purpose, and moral perfection), with the following description:

Humans have a religious side that is knotted on a sense of divinity. This sense of divinity is a primordial consciousness that is embedded in the human mind. As Hallaj said, "The primordial point which is both the source and the estuary, which never increases and decreases, does not run out by itself". ${ }^{46}$ Sense of divinity is part of the heart's potential (qalb) that exists in the human mind. The human heart basically has the potential to know the nature of everything, including knowledge of God. ${ }^{47}$ The heart is the deepest place of intelligence and wisdom, and becomes God's throne. ${ }^{48}$ When the eyes of the heart open, then the heart can penetrate the outer skin of something and reach the truth hidden in outward reality. ${ }^{49}$

Faith will prevent us from distorted understanding. ${ }^{50}$ The acknowledgment of faith in God, as the supernatural power that governs everything, is the basis for the growth of human religiosity. This growth will be stronger with one's consistency in worshiping and serving God.

Godhead indicates a life orientation that is not only worldly, but also ukhrawi. Confession of faith in God signifies a belief in eternal life with God, which is far more important than the life of the mortal world. Natural world is a place to find supplies hereafter. This orientation will make someone eager to worship and serve God, as a provision of pious deeds that will be rewarded in the hereafter.

Godhead is the initial foundation for moral perfection. A person's confession of faith in God will prevent him from doing something bad and despicable. A branch of faith is obedience to God's commands. ${ }^{51}$ Worship and devotion to God, in the end encourages someone to always do good, and maintain good morals.

\section{The Meaning of Humanity in the Perspective of Sufistic Psychology}

Semiotic humanity has the meaning that humans are the center of life, so that humans become the main responsibility in everything that happens in life, then humans are required to be fair and civilized. Philosophically, the precepts of humanity are part of universal humanity

${ }^{46}$ al-Hallaj, Tawasin; Kitab Kematian, Terj, Aisha 'Abdur Rahman, (Yogyakarta: Pustaka Sufi, 2002),

${ }^{47}$ al-Ghazali, Ihya Ulumiddin, Terj: Ismail Yakub, (Singapura: Pustaka Nasional, 1998), 914.

${ }^{48}$ Nanik Nurhayati, "Psikologi Sufi”, Jurnal an-Nuha, Vol. 1, No. 1, 2014.

${ }^{49}$ Rovi Husnaini, "Hati, Diri, dan Jiwa (Ruh)", Jaqfi: Jurnal Aqidah dan Filsafat Islam, n.n.

${ }^{50}$ Robert Frager, Psikologi Sufi untuk Transformasi Hati, Jiwa, dan Ruh, Terj: Hasmiyah Rouf, (Jakarta: Penerbit Zaman, 2014), 43.

51 al-Hujwiri, Kasyful Mahjub, translated: Ahmad Afandi, (Yogyakarta: Pustaka Sufi, 2003), 334. 
that shows egalitarianism and guarantees of human rights. This meaning in the perspective of Sufistic Psychology is seen in three principles (anthropho-religious-centric style, dual purpose, and moral perfection), with the following description:

Humanity puts man as the center of life which is basically religious. Humans have differences with other physical creatures. ${ }^{52}$ Humans are noble matter of light that is different from sensory matter. Religious people have the awareness to take full responsibility for themselves, the people around them and also their environment.

Humanity should not only be directed at worldly orientation. Worldly orientation is not able to produce strong motivation to uphold just and civilized human values. It is orientation to the afterlife that will make people excited about fair and civilized human values. Trust in reward and eternal life hereafter is a powerful motivation in forming responsible, just and civilized human beings.

High humanity is always equal to moral perfection. Perfect morality is the ultimate virtue. Humans are indeed covered by physical bodies, but they are revealed by their morality. ${ }^{\mathbf{5 3}}$ Humans with perfect morality are always able to show their noble humanity. This is because perfect morality makes people dare to be responsible for the consequences of their actions, and thinks whether their actions will have a positive or negative impact.

\section{The Meaning of Unity in Perspective of Sufistic Psychology}

Semiotic unity is interpreted as the existence of diversity which processes into one unit, it is necessary to have cooperation and harmony in realizing that unity. Philosophically, the unity of Indonesia embodies a national awareness and patriot spirit in shaping the independence of the nation, as well as joint efforts in achieving national goals. This meaning in the perspective of Sufistic Psychology is seen in three principles (anthropho-religious-centric style, dual purpose, and moral perfection), with the following description:

Unity will be stronger when imbued with religiosity. Religious motivation provides a strong foundation for unity and respect for diversity. This motivation enables one to see unity in diversity, because all things are God's light. Religious motivation also encourages the achievement of quality cooperation and true harmony.

Unity should not only be oriented towards the unification of worldly interests. Unity must also be oriented towards things that are ukhrawi. Cooperation and harmony are not only in the affairs of the world, but in the afterlife, by reminding each other in truth and patience. Cooperation in organizing pious deeds, building worship facilities, and supporting the realization of religious symbols.

${ }^{52}$ Musthafa Muhammad ath-Thair, Menyingkap Alam Ruh, Terj: Rofiq Zainul Mun'im, (Yogyakarta: Cahaya Hikmah, 2004), 33.

53 al-Qusayri, Risalah Qusayriyah, Terj: Ahsin Muhammad, (Bandung: Penerbit Pustaka, 1984), 237.

Teosofia: Indonesian Journal of Islamic Mysticism, Volume 7, Number 1, 2019 
True unity must be based on perfect morality. Unity is not only when it is in the same interests, or when there is personal gain. Unity is based on noble moral values. Cooperation and harmony also rely on morality. Cooperation is not justified in bad or destructive matters.

\section{The meaning of Citizenship in Successive Psychology Perspective}

Semiotic popularism is interpreted as people's sovereignty as the highest sovereignty, so that people's interests are the main priority. In arranging its interests, it is necessary to consult in the frame of wisdom or wisdom. Philosophically, this embodies the spirit of freedom, equality and brotherhood. The meaning in the perspective of Sufistic Psychology is seen in three principles (anthropo-religious-centric style, dual purpose, and moral perfection), with the following description: (1) Citizenship must rely on religious values. The sovereignty of the people with the priorities of the people's interests could not be contrary to religious values. The things that are beneficial to the people, could not be obtained from non-halal sources. The interests of the prioritized people must also be in harmony with religious values. (2) Citizenship is not only oriented to worldly interests. Daulat people with the priority of the people's interests must be directed to the lives of the people. (3) Citizenship should focus on perfect morality. Daulat people with the priority of the people's interests must be in harmony with moral values. The interests of the people, can be collective egoism, while ignoring humanity and morals. Especially if the motivation is only a worldly success. The wars and conflicts between nations, are the consequences of this collective egoism. ${ }^{54}$ Therefore, the consideration of wisdom is a requirement in the realization of the interests of the people.

\section{The Meaning of Social Justice in the Sufistic Psychology Perspective}

Social justice in a semiotic way is interpreted as togetherness in welfare which is realized by the existence of equality in an effort to eliminate social inequality. Philosophically, the principle of social justice is a conception of shared prosperity in the spirit of freedom while respecting individual creativity. The meaning in the perspective of Sufistic Psychology is seen in three principles (anthropo-religious-centric style, dual purpose, and moral perfection), with the following description:

Social justice will always be side by side with the religious dimension. Religious people, he will care more about social justice. Religiousity makes people able to share in togetherness and encourage the distribution of wealth, so that all elements of society will feel a common prosperity. Religion emphasizes the command to share and do equality of wealth, to realize a generous nature. This generosity is one of the four virtues which are the goals of religious Shari'a. ${ }^{55}$

\footnotetext{
${ }^{54}$ Hazrat Inayat Khan, Taman Mawar dari Timur, trans.: Nizamuddin Sadiq, (Yogyakarta: Putra Langit, 2001), 376 . 2002), 50 .

${ }^{55}$ Syah Waliyullah ad-Dahlawi, Pengetahuan Suci, trans.: Ribut Wahyudi, (Surabaya: Risalah Gusti,
} 
Social justice must be aimed at interests that include worldly and religious. Togetherness in prosperity, is not only meant to prosper by birth, but also to prosper inwardly. Equitable welfare, not only in material matters, but also in the distribution of knowledge and charity that is beneficial for the afterlife. Social justice will be stronger by relying on perfect morality. Togetherness in prosperity is driven by moral generosity that is far from stinginess and greed. Perfect morality will be easy in doing welfare equality, and supporting a socially just life.

\section{E. Concluding Remarks}

The meaning of Pancasila in the perspective of Sufistic Psychology rests on the principles of anthropo-centric-centric style, dual-purpose orientation, and moral perfection. The first principle, the One Godhead means commitment to strengthen the religious side. Life is oriented not only to the world, but also to the life of the hereafter. This divinity is the basic foundation in moral perfection. The second precept, Fair and Civilized Humanity, means human responsibility that is borne by humans, as the manager of the universe. The motivation of reward for achieving happiness will ultimately strengthen a sense of humanity that is just and civilized. The higher the human side, the more perfect morality. The third principle, Indonesian Unity means the recognition of diversity which is the source of the nation's wealth. Cooperation and harmony are needed to manage the wealth and realize national goals. True unity must be based on morality; cooperate and get along in noble matters, and in line with the truth. The fourth principle, Popularism Led by the Wisdom of Wisdom in Consultation Representatives means that the sovereignty of the people and their interests is a top priority. In preparing these priorities moral considerations are needed, and not only aimed at worldly interests, but also the interests of the faith. Then wisdom and wisdom are needed in formulating it. The fifth principle, Social Justice for All Indonesian People means that shared prosperity must be sought in equitable distribution. This welfare includes both physical and mental well-being, and is based on moral values. The meaning strengthens the position of Pancasila as the soul and personality of the Nation, and enriches the treasure of Pancasila as a source of national ethics.

\section{Bibliography}


Achmadi, Asmoro. Filsafat Umum. Jakarta: Raja Grafindo, 2011.

Arif, Syaiful. Falsafah Kebudayaan Pancasila; Nilai dan Kontradiksi Sosialnya. Jakarta: Gramedia, 2016.

Bakhtiar, Laleh. Mengenal Ajaran Kaum Sufi, trans. Purwanto. Bandung: Penerbit Marja', 2008.

ad-Dahlawi, Syah Waliyullah, Pengetahuan Suci, trans. Ribut Wahyudi. Surabaya: Risalah Gusti, 2002.

Eco, Umberto. Teori Semiotika. Yogyakarta: Kreasi Wacana, 2009.

Frager, Robert. Psikologi Sufi untuk Transformasi Hati, Jiwa, dan Ruh, Terj: Hasmiyah Rouf. Jakarta: Penerbit Zaman, 2014.

al-Ghazali. Ihya Ulumiddin, trans. Ismail Yakub. Singapura: Pustaka Nasional, 1998.

al-Ghazali. "Kimya'us Sa'adah: Pengungkapan Rahasia Kebahagiaan)" in Mutiara Ihya 'Ulumuddin, trans. H. Rus'an. Semarang: Wicaksana, 1984.

Hadziq, Abdullah. Rekonsiliasi Psikologi Sufistik dan Humanistik. Semarang: Rasail, 2005.

al-Hallaj. Tawasin; Kitab Kematian, trans. Aisha 'Abdur Rahman. Yogyakarta: Pustaka Sufi, 2002.

al-Hujwiri. Kasyful Mahjub, trans. Ahmad Afandi. Yogyakarta: Pustaka Sufi, 2003.

Husnaini, Rovi. "Hati, Diri, dan Jiwa (Ruh)", in Jaqfi: Jurnal Aqidah dan Filsafat Islam, tt.

Ismail, Fu'ad Farid dan Abdul Hamid Mutawalli. Cara Mudah Belajar Filsafat (Barat dan Islam), trans. Didin Faqihudin. Yogyakarta: IRCiSoD, 2012.

Karman, Yonky. "Fundamentalisme Pancasila." Kompas. Sabtu, June, 10, 2017.

Kartanegara, Mulyadi. Nalar Religius. Jakarta: Erlangga, 2007.

Kazhim, Musa. Tafsir Sufi. Jakarta: Lentera, 2003.

Khan, Hazrat Inayat. Taman Mawar dari Timur, trans. Nizamuddin Sadiq. Yogyakarta: Putra Langit, 2001.

Latif, Yudi. Negara Paripurna; Historisitas, Rasionalitas, dan Aktualitas Pancasila. Jakarta: Gramedia, 2015.

Nevid,Jeffrey S., dkk. Psikologi Abnormal Jilid I, trans. Jeanette Murad, dkk. Jakarta: Erlangga, 2003.

Nurhayati, Nanik. "Psikologi Sufi" in Jurnal an-Nuha, Vol. 1, No. 1, 2014. 
Qusayri, Al-. Risalah Qusayriyah, trans. Ahsin Muhammad. Bandung: Penerbit Pustaka, 1984. Sekretariat Negara Republik Indonesia. Risalah Sidang BPUPKI-PPKI. Jakarta: Sekretariat Negara Republik Indonesia, 1995.

Sumarsono. Filsafat Bahasa. Jakarta: Grasindo, 2004.

Suseno, Franz Magnis. Berebut Jiwa Bangsa. Jakarta: Penerbit Buku Kompas, 2006.

Syukur, Amin. Sufi Healing. Jakarta: Erlangga, 2012.

Syukur, Amin and Fatimah Usman. Insan Kamil; Paket Pelatihan Seni menata Hati. Semarang: Yayasan Al-Muhsinun Semarang, 2006.

Taniredja, Tukiran. Indonesia Baru; Empat Konsensus Satu Dasar Berbangsa dan Bernegara Indonesia. Yogyakarta: Penerbit Ombak, 2015.

Taufiq, Wildan. Semiotika untuk Kajian Sastra dan al-Qur'an. Bandung: Yrama Widya, 2016. 